\title{
Microbial Assisted Hexavalent Chromium Removal in Bioelectrochemical Systems
}

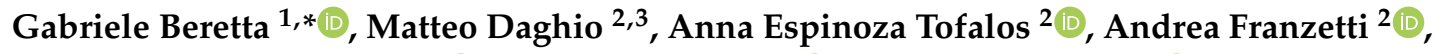 \\ Andrea Filippo Mastorgio ${ }^{1}$ (D) , Sabrina Saponaro ${ }^{1}$ (D) and Elena Sezenna ${ }^{1}$ (D) \\ 1 Department of Civil and Environmental Engineering, Politecnico di Milano, Piazza Leonardo da Vinci 32, \\ 20133 Milano, Italy; andreafilippo.mastorgio@polimi.it (A.F.M.); sabrina.saponaro@polimi.it (S.S.); \\ elena.sezenna@polimi.it (E.S.) \\ 2 Department of Earth and Environmental Sciences, University of Milano-Bicocca, Piazza della Scienza 1, \\ 20126 Milano, Italy; matteo.daghio@unimib.it (M.D.); anna.espinoza@unimib.it (A.E.T.); \\ andrea.franzetti@unimib.it (A.F.) \\ 3 Department of Agriculture, Food, Environment and Forestry, University of Florence, Piazzale delle Cascine \\ 18, 50144 Firenze, Italy \\ * Correspondence: gabriele.beretta@polimi.it; Tel.: +39-02-23996435
}

Received: 28 November 2019; Accepted: 5 February 2020; Published: 10 February 2020

\begin{abstract}
Groundwater is the environmental matrix that is most frequently affected by anthropogenic hexavalent chromium contamination. Due to its carcinogenicity, $\mathrm{Cr}(\mathrm{VI})$ has to be removed, using environmental-friendly and economically sustainable remediation technologies. BioElectrochemical Systems (BESs), applied to bioremediation, thereby offering a promising alternative to traditional bioremediation techniques, without affecting the natural groundwater conditions. Some bacterial families are capable of oxidizing and/or reducing a solid electrode obtaining an energetic advantage for their own growth. In the present study, we assessed the possibility of stimulating bioelectrochemical reduction of $\mathrm{Cr}(\mathrm{VI})$ in a dual-chamber polarized system using an electrode as the sole energy source. To develop an electroactive microbial community three electrodes were, at first, inserted into the anodic compartment of a dual-chamber microbial fuel cell, and inoculated with sludge from an anaerobic digester. After a period of acclimation, one electrode was transferred into a polarized system and it was fixed at $-0.3 \mathrm{~V}$ (versus standard hydrogen electrode, SHE), to promote the reduction of $1000 \mu \mathrm{g} \mathrm{Cr}(\mathrm{VI}) \mathrm{L}^{-1}$. A second electrode, served for the set-up of an open circuit control, operated in parallel. $\mathrm{Cr}(\mathrm{VI})$ dissolved concentration was analysed at the initial, during the experiment and final time by spectrophotometric method. Initial and final microbial characterization of the communities enriched in polarized system and open circuit control was performed by $16 \mathrm{~S}$ rRNA gene sequencing. The bioelectrode set at $-0.3 \mathrm{~V}$ showed high $\mathrm{Cr}(\mathrm{VI})$ removal efficiency (up to $93 \%$ ) and about $150 \mu \mathrm{g} \mathrm{L}^{-1}$ day $^{-1}$ removal rate. Similar efficiency was observed in the open circuit (OC) even at about half rate. Whereas, purely electrochemical reduction, limited to $35 \%$, due to neutral operating conditions. These results suggest that bioelectrochemical $\mathrm{Cr}(\mathrm{VI})$ removal by polarized electrode offers a promising new and sustainable approach to the treatment of groundwater $\mathrm{Cr}(\mathrm{VI})$ plumes, deserving further research.
\end{abstract}

Keywords: bioelectrochemical systems (BESs); hexavalent chromium; electrobioremediation; groundwater treatment

\section{Introduction}

Extensive use of chromium $(\mathrm{Cr})$ and its compounds in many industrial process [1] and refractory production has made it a major pollutant [2]. The mobility, bioavailability and toxicity of chromium depend on its oxidation states. In the natural environment, $\mathrm{Cr}(\mathrm{III})$ is most immobile, less soluble and 
stable. Whereas, $\mathrm{Cr}(\mathrm{VI})$ is highly mobile, soluble and bioavailable. Compared with $\mathrm{Cr}(\mathrm{III}), \mathrm{Cr}(\mathrm{VI})$ is also extremely toxic (by 100 times) to living organisms and it is internationally recognized as a human carcinogen, mutagen and teratogen.

To reduce its impact on human health and the environment, appropriate remedial measures and remediation interventions are needed. The recovery and removal of chromium from wastewater or groundwater is traditionally carried out by adsorption, [3,4], chemical or electrochemical reduction to $\mathrm{Cr}(\mathrm{III})$, and subsequent precipitation [5,6] or electrokinetics [7]. These methods bring with them some disadvantages that concern high-energy requirements, excessive chemical consumption, production of unwanted secondary products and residual highly concentrated toxic sludge $[1,5]$. Furthermore, some of these approaches are quite effective at the high chromium concentrations $[3,7]$ of industrial effluents. Whereas, the removal efficiency greatly decreases at low concentrations, as typically observed in natural surface and groundwater.

Bioremediation, exploiting the huge microbial metabolic capacity to transform contaminants into harmless substances, may overcome some of the drawbacks of physical-chemical technologies, and is a low energy and cost-effective process. Microbes naturally adopt different strategies to survive in chromium polluted environment, such as biosorption, bioaccumulation and biotransformation for detoxification of $\mathrm{Cr}(\mathrm{VI})$ into the relatively safe $\mathrm{Cr}(\mathrm{III})$ form [8]. Bioremediation of $\mathrm{Cr}(\mathrm{VI})$ includes all these mechanisms and may be promoted through the addition of nutrients and/or electron donors to sustain microbial growth (biostimulation), or even by the injection of selected bacterial strains that are able to reduce $\mathrm{Cr}(\mathrm{VI})$ and enhance the removal process (bioaugmentation).

Recently, great attention has been also paid to Microbial Electrochemical Technology (MET) as an innovative and sustainable approach for promoting the bioremediation of contaminated sites [9]. In METs, microorganisms catalyze the oxidation or reduction of pollutants using solid-state electrodes as virtually inexhaustible electron acceptors or donors [10-12].

MET has achieved promising results in the treatment of wastewater contaminated with $\mathrm{Cr}(\mathrm{VI})$. In microbial fuel cells (MFCs), a representative of MET, $\mathrm{Cr}(\mathrm{VI})$ in industrial effluents could be effectively reduced in either, abiotic cathodic chambers, under acidic conditions [13-16] or biocathodes in the neutral $\mathrm{pH}$ range [17,18], while generating electricity from low-grade anodic organic substrates. $\mathrm{Cr}(\mathrm{VI})$ can also be removed in systems relying on an external power supply for creating a bias between two electrodes or a potentiostat to supplement electrons to the cathode $[19,20]$.

Under anaerobic conditions, $\mathrm{Cr}(\mathrm{VI})$ can serve as the final electron acceptor in a process that usually involves membrane-bound reductases [21], but also soluble enzymes (e.g., c3 cytochrome in Desulfovibrio v.) [22]. Previous work has confirmed $\mathrm{Cr}(\mathrm{VI})$ autotrophic reduction in soil-aquifer that has involved different species of microorganisms (e.g., Clostridium chromiireducens sp., Pseudomonas Synxantha) that are able to use hydrogen and $\mathrm{CO}_{2} / \mathrm{NaHCO}_{3}$ as an electron donor, and carbon source, respectively [23-26]. In the wide variety of bacteria capable of efficient $\mathrm{Cr}(\mathrm{VI})$ reduction [27] some, belonging to the species Shewanella sp. [20], Desulfovibrio sp. [22], Pseudomonas sp. [28], Trichococcus sp. [18], Stenotrophomonas sp., Serratia sp., and Achromobacter sp. [29] have been in fact reported to be able to use an electrode as electron donor and $\mathrm{Cr}(\mathrm{VI})$ as electron acceptor.

The advantages to exploiting the ability of these microorganisms to bioremediate ensures issues in electron donors delivery and availability to be avoided, and improved control of parasitic reactions to avoid the formation of unwanted daughter products [9]. Moreover, the production of an electrical signal can act as a biosensor for real-time monitoring of the microbial activity [30,31].

This work aimed to determine the effectiveness of a microbial biocathode for CrVI reduction in comparison to a pure microbial and pure electrochemical control, to start exploring the possibility of effective $\mathrm{Cr}(\mathrm{VI})$ reduction in natural surface water or groundwater at lower $\mathrm{Cr}(\mathrm{VI})$ concentrations than wastewater so far investigated. Therefore, an initial concentration of $\mathrm{Cr}(\mathrm{VI})$ of $1 \mathrm{mg} \mathrm{L}^{-1}$ was applied and no organic substance was added during the chromium removal phase. To minimize the total energy required and to facilitate the rapid development of an electroactive microbial biofilm, we divided our work into two phases. In the first phase, electrodes were acclimated in the anodic chamber 
of MFC, inoculated with anaerobic digester sludge. Once the electroactive biofilm has developed, one of the electrodes was transferred in a dual-chamber potentiostatically-controlled system (POL $-0.3 \mathrm{~V})$ and -0.3 V versus Standard Hydrogen Electrode (SHE) potential was imposed (unless otherwise stated, all potentials throughout the paper are relative to SHE). To approach real groundwater conditions, differently from previous studies [32-34], no organic substance was added in the working chamber, dosing carbonates as the sole carbon source.

\section{Materials and Methods}

\subsection{Reactors Set-Up and Operation}

For this study, five identical double-chamber ("H-shaped”) reactors have been set up (Figure 1). Each reactor consisted of a pair of borosilicate-glass bottles, 1.2 L useful volume each one. The connection between anolyte and catholyte was achieved by a proton exchange membrane (PEM, $4.52 \mathrm{~cm}^{2}$, Nafion117, FuelCellsEtc, College Station, TX, USA) placed between bottles. Graphite cylinders (ATAL Grafiti, Trezzo sull'Adda, Italy, length $6 \mathrm{~cm}$, diameter $1 \mathrm{~cm}$, geometric area $18.85 \mathrm{~cm}^{2}$ ) served as electrodes, both anodes and cathodes. Stainless steel cables $(\varnothing 0.1 \mathrm{~cm})$ fixed in the centre of the graphite cylinders were used as current collectors. All cables were covered with heat-shrinkable polytetrafluoroethylene (PTFE) tubes (Sigma-Aldrich, Milan, Italy) to limit corrosion phenomena. The distance between anode and cathode within the system was about $10 \mathrm{~cm}$. In the experiments, a mineral medium $\left(7 \mathrm{~g} \mathrm{~L}^{-1} \mathrm{NaH}_{2} \mathrm{PO}_{4} \cdot 12 \mathrm{H}_{2} \mathrm{O}, 3 \mathrm{~g} \mathrm{~L}^{-1} \mathrm{KH}_{2} \mathrm{PO}_{4}, 1 \mathrm{~g} \mathrm{~L}^{-1} \mathrm{NH}_{4} \mathrm{Cl}\right.$ and $\left.0.5 \mathrm{~g} \mathrm{~L}^{-1} \mathrm{NaCl}\right)$, pre-autoclaved at $120^{\circ} \mathrm{C}$ for 30 min twice, was used as electrolyte and to support microbial growth. For the entire duration of the test, all the systems were kept at a constant temperature and $\mathrm{pH}$, respectively, $18 \pm 1^{\circ} \mathrm{C}$ and $7.4 \pm 0.1$.
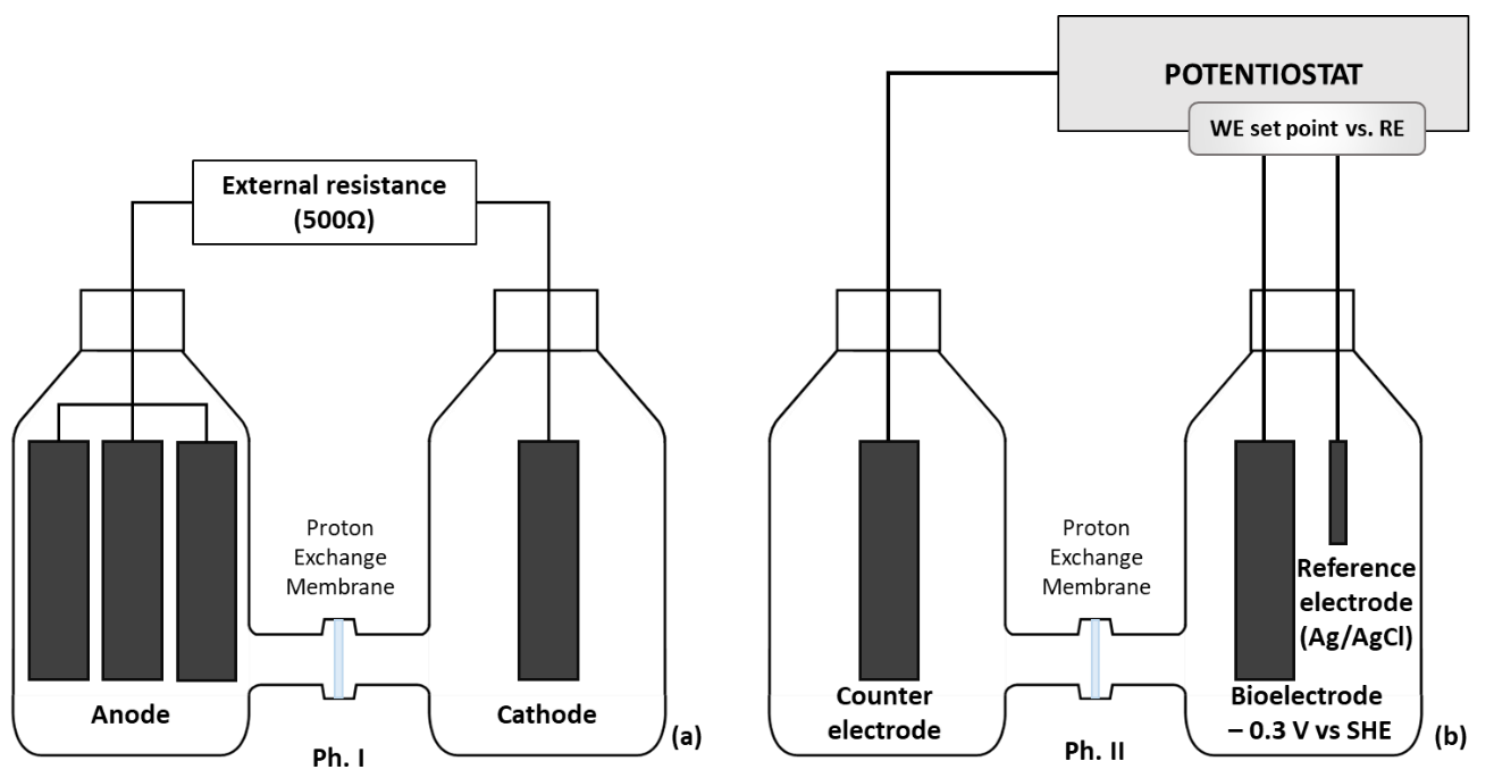

Figure 1. Schematic diagram of the reactors used in the present study. (a) In the acclimatization phase (Ph. I) of the electroactive biofilm (MFC), anode and cathode were connected by a $500 \Omega$ external resistance. (b) In the second phase (Ph. II), in the polarized reactor (POL $-0.3 \mathrm{~V}$ ) and in the abiotic polarized control $(\mathrm{ABI}-0.3 \mathrm{~V})$, a potential of $-0.3 \mathrm{~V}$ versus SHE was imposed.

\subsection{Electroactive Biofilm Development in MFC}

In the first phase of the work, a MFC was set up in one of the previously described reactors, in order to develop anodic biofilm able to use the anode as the main electrons acceptor (Figure 1a). Three electrodes were placed in the anode chamber in parallel, to simultaneously develop an electroactive biofilm on all three electrodes, and one in the cathodic chamber. The anodic chamber was inoculated 
with anaerobic digester sludge $(0.24 \mathrm{~L}$, corresponding to $20 \%$ of the volume) and then sodium acetate was added, up to a concentration of $0.1 \mathrm{~g} \mathrm{~L}^{-1}$, as the carbon source for microbial growth. To establish anaerobic conditions, during the set-up, the anodic solution was flushed with nitrogen and the chamber immediately sealed with screw caps fitted with PTFE/silicone gaskets. The cathode chamber, filled with mineral medium, was kept open to air to allow oxygen diffuse into the solution.

For the entire duration of the test, in the external circuit connecting anode and cathode, a constant resistance $(500 \Omega$ ) was maintained and voltage drop continuously recorded (PicoLog 1012, Pico Technology Ltd., Eaton Socon, UK). This allowed the produced current density to be monitored over time, and to spike further sodium acetate into the anodic compartment, as soon as current density below $0.5 \mathrm{~mA} \mathrm{~m}^{-2}$ was recorded.

In this first phase, for the characterization of the microbial community, two samples were taken: A sample from anaerobic sludge, used as an inoculum in MFC ( $\mathrm{t} 0 \mathrm{Ph}$. I), and a sample of the anodic solution, used to inoculate the potentiostatically-controlled tests in the following experimental phase (t0 Ph. II).

\subsection{Polarized Bio-Electrode for Cr(VI) Removal}

Two out three graphite cylinders, acclimated in the anodic chamber of the MFC, were used to set up (i) the polarized system at $-0.3 \mathrm{~V}$ versus SHE for the removal of $\mathrm{Cr}(\mathrm{VI})$ (POL $-0.3 \mathrm{~V}$ ), and (ii) an open circuit control (OC). The configuration of the systems is the same as described above (Figure 1b). The acclimatized bio-electrode was immersed in the polarized system working chamber filled with mineral medium, $\mathrm{KHCO}_{3}\left(2 \mathrm{~g} \mathrm{~L}^{-1}\right)$ as the sole source of carbon, and $\mathrm{K}_{2} \mathrm{Cr}_{2} \mathrm{O}_{7}(\mathrm{Cr}(\mathrm{VI}) 1 \mathrm{mg} \mathrm{L}-1)$. The working chamber housed an $\mathrm{Ag} / \mathrm{AgCl}$ reference electrode ( $0.2 \mathrm{~V}$ versus $\mathrm{SHE})$. In addition to the biofilm on the electrode, the same chamber was inoculated with $0.24 \mathrm{~L}$ of solution from the anodic chamber of the MFC. To minimize the amount of dissolved organic carbon, the inoculum was first subjected to a washing procedure, by repeated centrifugation (10 min at $4000 \mathrm{rpm}$, Thermo Scientific) and resuspension of the pellet in fresh mineral medium. The counter electrode chamber was filled up with the same volume of mineral medium and $\mathrm{KHCO}_{3}$ as used for the working chamber. POL $-0.3 \mathrm{~V}$ has been connected to a dual-channel potentiostat controlled by an Arduino board (Politecnico di Milano I3N-DICA, 2016 Cariplo-BEvERAGE) and a potential of $-0.3 \mathrm{~V}$ was imposed to the bioelectrode. As described in $[35,36]$, the potentiostat-board allows setting potential to the bioelectrode, that act as working electrode (WE), at set point (i.e., $-0.3 \mathrm{~V}$ versus $\mathrm{SHE}$ ) against an $\mathrm{Ag} / \mathrm{AgCl}$ reference electrode $(+0.2 \mathrm{~V}$ versus SHE) placed in the same chamber of the WE. The third electrode acts as counter electrode (CE) and potentiostat adjusts the current flow in CE to maintain the fixed potential to the WE.

The OC system, to assess the biological $\mathrm{Cr}(\mathrm{VI})$ reduction, was set up exactly like POL $-0.3 \mathrm{~V}$ without connecting the external circuit. Two abiotic control reactors were also set up (i) ABI $-0.3 \mathrm{~V}$ in which a new electrode was polarized at $-0.3 \mathrm{~V}$, to evaluate electrochemical $\mathrm{Cr}(\mathrm{VI})$ removal and (ii) ABI-OC, in which no potential was imposed to assess any absorption phenomena. The configuration of the abiotic controls was the same as the POL $-0.3 \mathrm{~V}$. The solutions were sterilized in an autoclave twice $\left(120^{\circ} \mathrm{C}\right.$ for $\left.30 \mathrm{~min}\right)$ before filling up abiotic controls.

$\mathrm{Cr}(\mathrm{VI})$ removal test POL $-0.3 \mathrm{~V}$ and OC lasted respectively 6 and 12 days, until more than $90 \%$ chromium removal was reached. Whereas abiotic tests (ABI -0.3 V and ABI-OC) lasted 12-14 days until no further changes in chromium concentrations were observed. Through these different systems, it was possible to compare the reduction of $\mathrm{Cr}(\mathrm{VI})$ exclusively by the electrochemical, biological and bio-electrochemical way.

The different phases of the experimental work, the acronyms used and their descriptions are summarized in Table 1 and Figure 2. 
Table 1. Summary table of the experimental work.

\begin{tabular}{|c|c|c|c|c|c|}
\hline Work Phase & Description & Acronym & Carbon Source & $\begin{array}{l}\text { Hexavalent } \\
\text { Chromium }\end{array}$ & $\begin{array}{c}\text { Microbial } \\
\text { Characterization }\end{array}$ \\
\hline \multirow{2}{*}{$\begin{array}{l}\text { Electroactive } \\
\text { bacteria } \\
\text { enrichment }\end{array}$} & Inoculum in MFC & t0 Ph. I & $\begin{array}{l}\text { Organic matter } \\
\text { (anaerobic } \\
\text { sludge) }\end{array}$ & - & \multirow[t]{2}{*}{ Planktonic community } \\
\hline & $\begin{array}{c}\text { MFC until 15th } \\
\text { day-inoculum of } \\
\text { POL }-0.3 \mathrm{~V} \text { and OC }\end{array}$ & t0 Ph. II & Acetate & - & \\
\hline \multirow{4}{*}{$\begin{array}{l}\mathrm{Cr}(\mathrm{VI}) \text { removal } \\
\text { tests }\end{array}$} & $\begin{array}{l}\text { Potentiostatically } \\
\text { controlled system }\end{array}$ & POL $-0.3 \mathrm{~V}$ & \multirow[t]{4}{*}{$\mathrm{KHCO}_{3}$} & \multirow{4}{*}{$\begin{array}{l}\mathrm{K}_{2} \mathrm{Cr}_{2} \mathrm{O}_{7} \\
\left(1 \mathrm{mg} \mathrm{L}^{-1}\right. \\
\mathrm{Cr}(\mathrm{VI}))\end{array}$} & $\begin{array}{l}\text { Planktonic community } \\
\text { and biofilm developed } \\
\text { on polarized electrode } \\
\text { (POL }-0.3 \mathrm{~V} \text { electrode) }\end{array}$ \\
\hline & Open circuit control & OC & & & $\begin{array}{c}\text { Planktonic community } \\
\text { and biofilm developed } \\
\text { on graphite (OC } \\
\text { graphite) }\end{array}$ \\
\hline & $\begin{array}{l}\text { Potentiostatically } \\
\text { controlled abiotic } \\
\text { system }\end{array}$ & $\mathrm{ABI}-0.3 \mathrm{~V}$ & & & - \\
\hline & $\begin{array}{l}\text { Open circuit abiotic } \\
\text { control }\end{array}$ & ABI-OC & & & - \\
\hline
\end{tabular}

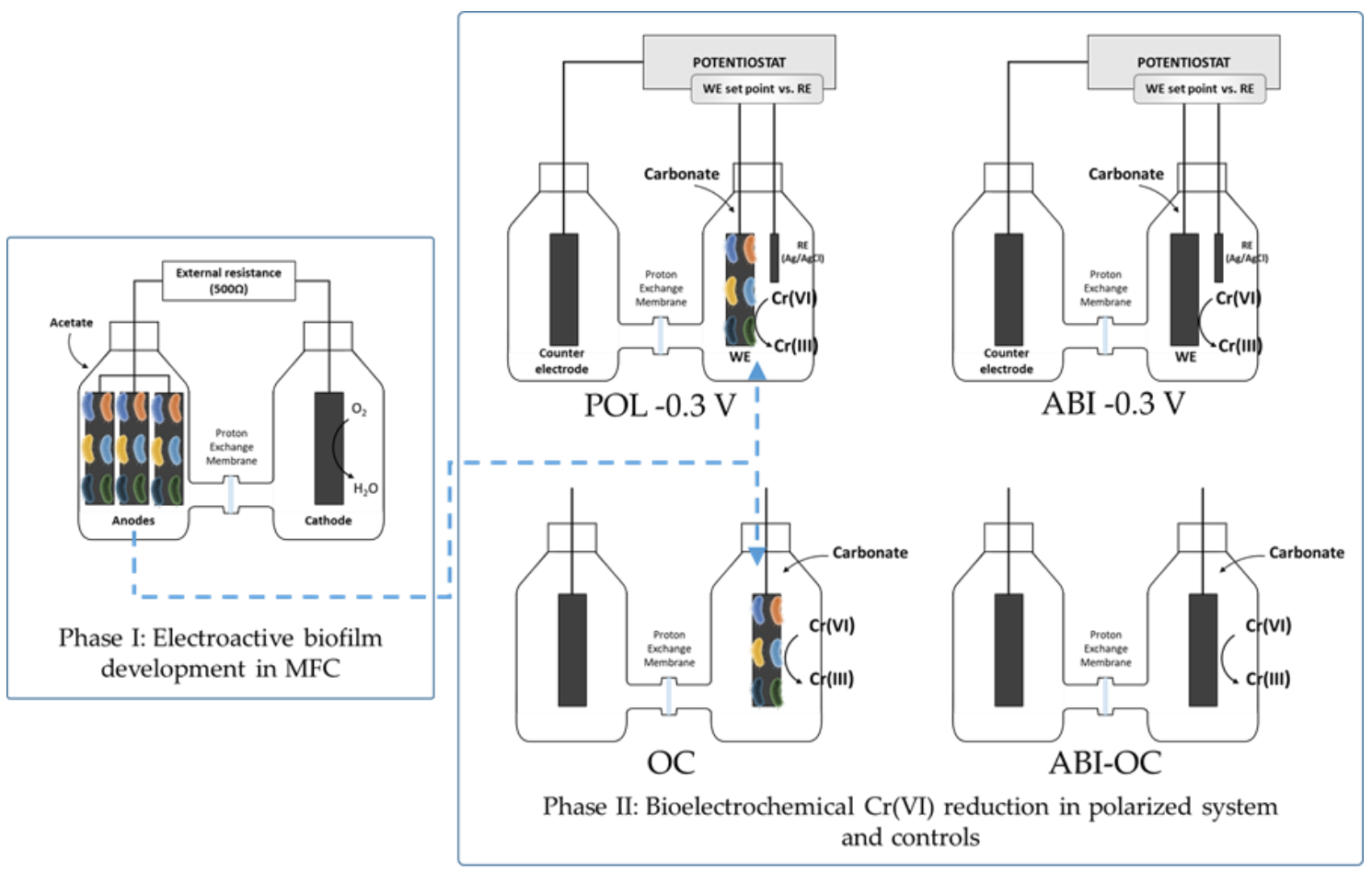

Figure 2. Conceptual model of the experimental work.

\subsection{Analyses and Data Processing}

The samples were periodically collected from all the systems for the analysis of $\mathrm{Cr}(\mathrm{VI})$ by means of a spectrophotometer (DR 6000, Hach Company, Loveland, CO, USA), according to the APHA Standard Methods 3500-B method [37]. Detection limit of spectrophotometric method was $18 \mu \mathrm{g}$ $\mathrm{Cr}(\mathrm{VI}) \mathrm{L}^{-1}$. Only $\mathrm{Cr}(\mathrm{VI})$ was monitored because of its soluble form and because the risks for human health associated with the trivalent forms of dissolved chromium are much lower, compared to $\mathrm{Cr}(\mathrm{VI})$.

To characterize the microbial communities, (i) samples of the anaerobic sludge, the anodic solution of the MFC and the solutions of OC and POL $-0.3 \mathrm{~V}$ were filtered on $0.45 \mu \mathrm{m}$ sterile paper filters and 
(ii) the biofilms attached to the POL $-0.3 \mathrm{~V}$ electrode and OC graphite were scraped with a sterile scalpel obtaining graphite powder and biofilm. The genomic DNA was extracted using the FastDNA Spin Kit for Soil (MP Biomedicals, Solon, OH, USA) according to the manufacturer's instructions. The V5-V6 hypervariable regions of the 16S rRNA gene were PCR-amplified using the 783F and 1046R primers [38,39]. The bacterial PCR was performed in $20 \mu \mathrm{L}$ volume reactions with GoTaq ${ }^{\circledR}$ Green Master Mix (Promega Corporation, Madison, WI, USA) and $1 \mu \mathrm{M}$ of each primer. After the amplification, DNA quality was evaluated spectrophotometrically and DNA was quantified using Qubit ${ }^{\circledR}$ (Life Technologies, Carlsbad, CA, USA). The sequencing was carried out at Consorzio per il Centro di Biomedicina Molecolare (CBM). Bioinformatics elaborations have been performed as previously reported [40]. Classification of the representative sequences of each Operational Taxonomic Unit (OTU) was done using the RDP classifier ( $\geq 80 \%$ confidence) [41]. Rarefaction curves, OTU richness, Shannon and Chao1 alpha-diversity indices were generated for each sample using $R$ (vegan).

\subsection{Calculations}

The MFC current was calculated as $I=V / R(\mathrm{~A})$, where $V(\mathrm{~V})$ is the voltage drop across the external resistance, $R$ (in $\Omega$ ). The current density $\left(\mathrm{mA} \mathrm{m}^{-2}\right)$ was calculated as $J=I / A E$ where $A E$ is the geometric area of the electrode $\left(\mathrm{m}^{2}\right)$. Coulombic efficiency $(\mathrm{EC})$ is the percentage of electrons circulating in the system, compared to the total electrons theoretically present in the oxidizable organic substrate (Equation (1)). The EC of the MFC, therefore, indicates the microbial conversion efficiency of the substrate into electric current. EC was calculated by assuming the dosed acetate as the only oxidizable substrate and sole electron source in the reactors,

$$
E C=\frac{(M I \Delta t)}{\left(F b V_{a n} \Delta S\right)}
$$

where $M\left(59 \mathrm{~g} \mathrm{~mol}^{-1}\right)$ is the molecular weight of $\mathrm{CH}_{3} \mathrm{COO}^{-}, I(\mathrm{~A})$ the recorded current in time $\Delta t$ (s). F is the Faraday constant $\left(96,485.3\right.$ Coulomb mol$^{-1}$ of electrons $), b$ is the stoichiometric factor $=8$ moles of electrons per mole of acetate, $V_{a n}(\mathrm{~L})$ is the volume of the anodic compartment in the MFC and $\Delta S$ the consumed substrate over time $\left(\mathrm{g} \mathrm{L}^{-1}\right)$. The consumed substrate was calculated by assuming the complete oxidation of acetate recorded current was below $0.5 \mathrm{~mA} \mathrm{~m}^{-2}$.

Chromium removal efficiency was calculated by considering the percentage residual dissolved $\mathrm{Cr}(\mathrm{VI})$ concentration with time, or,

$$
\text { Residual } \operatorname{Cr}(V I)=\frac{C(t)}{C_{0}} \times 100
$$

where $C_{0}\left(\mu \mathrm{g} \mathrm{L}^{-1}\right)$ and $C(t)\left(\mu \mathrm{g} \mathrm{L}^{-1}\right)$ are the initial concentration and concentration at time $t$ (days), respectively. $\mathrm{Cr}(\mathrm{VI})$ removal efficiency with time is therefore:

$$
C r(V I) \text { removal ef ficiency }=\left(1-\frac{C(t)}{C_{0}}\right) \times 100
$$

\section{Results}

\subsection{Current Density in the MFC}

The current density in the MFC, throughout the experiment, varied from a minimum of $0.5 \mathrm{~mA} \mathrm{~m}^{-2}$ to a maximum of $237 \mathrm{~mA} \mathrm{~m}^{-2}$ (Figure 3). At the beginning of the test, from the set-up (day 0 ) to the first spike of acetate (day 3), the current density and the EC reached the peak values of, respectively, $160 \mathrm{~mA} \mathrm{~m}^{-2}$, and $2.5 \%$. Following the third addition of acetate (day 7), both an increase in current density ( $\max \sim 230 \mathrm{~mA} \mathrm{~m}{ }^{-2}$ ) and in EC (18\%) was observed. Even after the fourth addition of acetate, the response of the system in terms of current density was the same for previous spikes (max $\sim 230 \mathrm{~mA} \mathrm{~m}^{-2}$ ), while the EC value (16.5\%) was slightly reduced. The decrease in EC was probably 
due to the cathodic reaction [42] limiting the overall process, and thus, favouring acetate consumption by different metabolic pathways (acetoclastic methanogenesis) instead of the anode-using ones [43].

After 15 days from the MFC set-up, two out three electrodes and $0.24 \mathrm{~L}$ of solution from the anodic chamber were removed for the set-up of POL $-0.3 \mathrm{~V}$ and open-circuit systems. The removed anolyte was replaced by an equal volume of mineral medium and acetate $\left(0.1 \mathrm{~g} \mathrm{~L}^{-1}\right)$. The current density in the cycles, following renewal, immediately reached the same peak values recorded in the previous cycles, confirming the cathodic reaction as the limiting step in the whole process. The EC, vice versa, gradually increased up to about $14 \%$. The trend in both the currents and the ECs, before, and after, electrode transfer and the renewal of the medium, shows that the microbial community from the initial inoculum, following an adaptation phase, was able to develop a biofilm able to oxidize the acetate and to transfer electrons to the anode with a discrete efficiency.

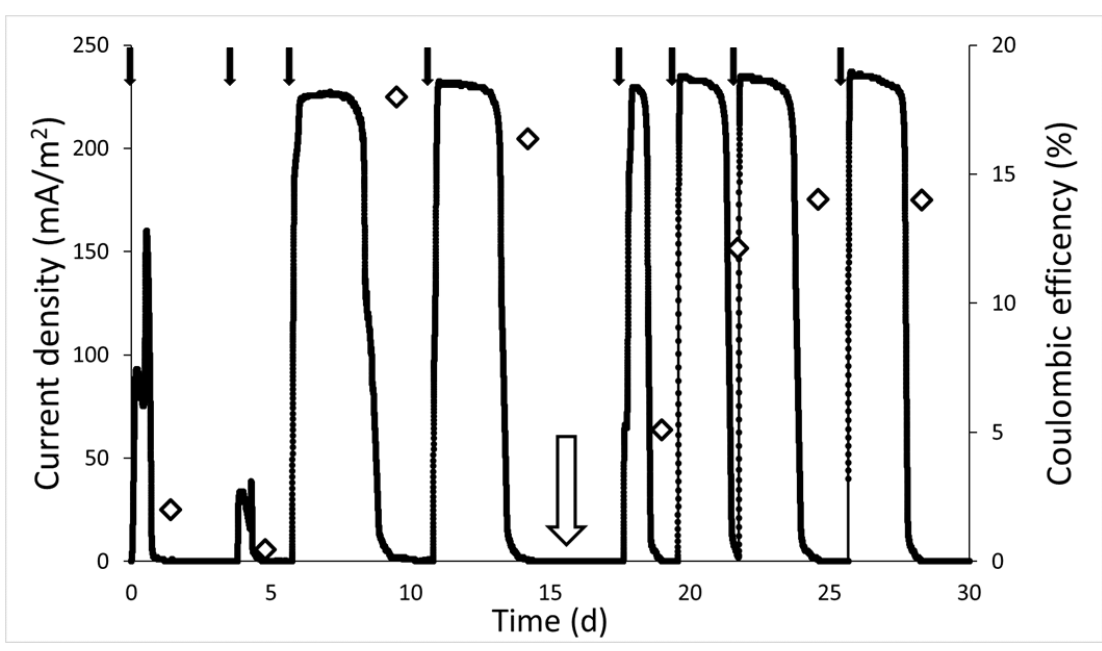

Figure 3. Current density and Coulombic Efficiency trend. Current density (black line) produced by electroactive biofilm after periodic acetate addition (black arrows) until the solution was renewed (white arrow) and two of the three electrodes used to set up POL $-0.3 \mathrm{~V}$ and OC. The EC was calculated (empty diamond) at the end of each current peak.

\section{2. $\mathrm{Cr}(\mathrm{VI})$ trends}

Biological $\mathrm{Cr}(\mathrm{VI})$ reduction, either in the POL $-0.3 \mathrm{~V}$ and $\mathrm{OC}$, outstanded the abiotic reduction. In the POL $-0.3 \mathrm{~V}$ system, a rapid decrease in the concentration of dissolved hexavalent chromium was observed (Figure 4). After 6 days from test set-up, the residual concentration in POL $-0.3 \mathrm{~V}$ was equal to $92.1 \pm 13.2 \mu \mathrm{g} \mathrm{L}^{-1}$, corresponding to a removal rate of about $151 \mu \mathrm{g} \mathrm{L}^{-1}$ day $^{-1}$. A slower removal rate, about $75 \mu \mathrm{g} \mathrm{L}{ }^{-1}$ day $^{-1}$, approximately half the POL $-0.3 \mathrm{~V}$, was registered in the the OC test. However, the overall removal was relevant, with low residual $\mathrm{Cr}(\mathrm{VI})$ concentration at the end of the test of $24.6 \pm 7.7 \mu \mathrm{g} \mathrm{L}^{-1}$.

In both the bioreduction tests, $\mathrm{POL}-0.3 \mathrm{~V}$ and $\mathrm{OC}, \mathrm{Cr}(\mathrm{VI})$ reduction rate was not influenced by a declining in the $\mathrm{Cr}(\mathrm{VI})$ concentration. We hypothesise that, in our biological tests, $\mathrm{Cr}(\mathrm{VI})$ could be used as a terminal electron acceptor [44,45]. The higher removal rate in the polarized system might be ascribed to a larger array of electron donors, with respect to the open circuit control. In addition to endogenous electron reserves, the electrode posed at $-0.3 \mathrm{~V}$ can act as a further electron source [46], that could have promoted chromium reduction. Additional biological mechanisms of chromium reduction, such as enzyme reduction (soluble or membrane-associated reductase) [21], intracellular detoxification mechanisms $[45,47]$ and adsorption on the cell surface $[48,49]$ may have occurred equally in both biological systems.

ABI-OC showed adsorption onto materials did not provide any significant contribution to the removal of $\mathrm{Cr}(\mathrm{VI})$, with an overall efficiency not exceeding $3 \%$ in the operational conditions of the test. 
In $\mathrm{ABI}-0.3 \mathrm{~V}$ about $35 \%$ removal was recorded over 12 days. Following an initial rapid decline, in the first 3 days, about $68.5 \mu \mathrm{g} \mathrm{L}^{-1}$ day $^{-1}, \mathrm{Cr}(\mathrm{VI})$ removal rate slowed down, leading in about a week to an asymptotic residual concentration of $728 \pm 35 \mu \mathrm{g} \mathrm{L}^{-1}$, corresponding to $31 \mu \mathrm{g} \mathrm{L}^{-1}$ day $^{-1}$ average removal rate. This purely electrochemical $\mathrm{Cr}(\mathrm{VI})$ reduction appears to be somehow limited by the operating conditions, neutral $\mathrm{pH}(7.4 \pm 0.1)$ and poised working electrode potential, as already pointed out, even at higher initial $\mathrm{Cr}(\mathrm{VI})$ concentrations, in previous experiences [50,51]. Moreover, as already reported in other studies, $\mathrm{Cr}$ (III) precipitation could passivate the electrode further limiting $\mathrm{Cr}(\mathrm{VI})$ reduction [14].

By comparing $\mathrm{Cr}(\mathrm{VI})$ removal rates in the different tests, it is possible to observe how, in our experimental conditions, biolelectrochemical reduction in POL $-0.3 \mathrm{~V}$, about $150 \mu \mathrm{g} \mathrm{L}{ }^{-1} \mathrm{Cr}(\mathrm{VI})$, appears to be about $20 \%$ faster than the simple superimposition of purely electrochemical and bioreduction mechanisms (31.4 $\mu \mathrm{g} \mathrm{L}^{-1}$ day $^{-1}$ in $\mathrm{ABI}-0.3 \mathrm{~V}$ and $75 \mu \mathrm{g} \mathrm{L}-1$ in $\left.\mathrm{OC}\right)$.

Due to the presence of an electroactive biofilm in this study, it was possible to observe more than $90 \%$ hexavalent chromium reduction at neutral $\mathrm{pH}$. Conversely, in previous studies, the electrochemical reduction of $\mathrm{Cr}(\mathrm{VI})$ was found to be strongly dependent on the $\mathrm{pH}$ of the cathodic solution $[13,15]$. Singhvi and Chhabra demonstrated low $\mathrm{pH}$ increases the reduction rate of $\mathrm{Cr}(\mathrm{VI})$ to $\mathrm{Cr}(\mathrm{III})$ and the concomitant production of electrical energy in abiotic cathodes, while Gangadharan and Nambi did not observe any reduction in a cathodic solution at $\mathrm{pH} 7[50,52]$.

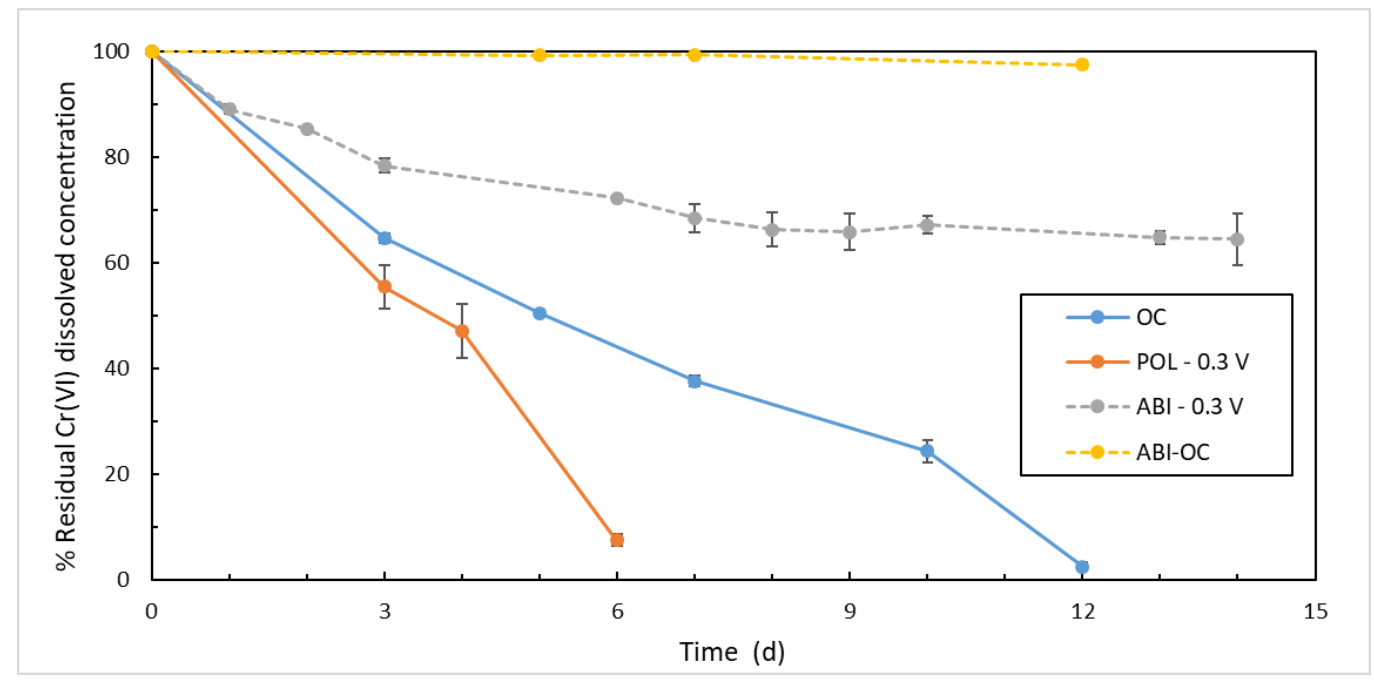

Figure 4. Reduction of $\mathrm{Cr}(\mathrm{VI})$ concentrations over time in ABI-OC (yellow dashed line), OC (blue solid line), POL $-0.3 \mathrm{~V}$ (orange solid line), ABI $-0.3 \mathrm{~V}$ (pink dashed line).

\subsection{Microbial Communities}

From the four samples, a total of 98,719 amplicon reads were obtained. Rarefaction curves showed an appreciable representation of the real OTU richness for four samples (t0 Ph. II, OC, POL $-0.3 \mathrm{~V}$ and POL - 0.3 V electrode) (Figure S1). Whereas, the observed OTU richness is probably an underestimation of the real richness of samples $\mathrm{t} 0 \mathrm{Ph}$. I and OC graphite. To overcome this underestimation, the Chao1 index was calculated, in order to estimate the exact richness [53]. Data analysis shows that the diversity of the microbial communities decreased on the electrodes compared with the bulks. The decrease in diversity was shown by both a decrease in the Shannon and Chao1 indices from the bulks (Shannon: ranging from 4.33 for $\mathrm{POL}-0.3 \mathrm{~V}$ to 4.43 for $\mathrm{OC}$; Chao1: ranging from 333.23 for t0 $\mathrm{Ph}$. I to 635.19 for POL $-0.3 \mathrm{~V}$ ), compared to the electrodes (Shannon: 4.14 for OC graphite and 3.68 for POL $-0.3 \mathrm{~V}$ electrode; Chao1: 343.77 for OC graphite and 437.00 for POL $-0.3 \mathrm{~V}$ electrode). These decreases in diversity likely resulted from the selection of electroactive microorganisms on the electrodes (Table S1). 
The results of the microbiological analyses showed an evolution bacterial community to begin from the inoculum ( $\mathrm{t} 0 \mathrm{Ph}$. I) to the inoculum of POL $-0.3 \mathrm{~V}$ and OC (t0 Ph. II) (Figure 5). The microbial communities show an increase in the relative abundance of bacteria belonging to the Burkholderiales (from $<1.5$ to $25.5 \%$ ), Bacteroidales (from 3.1 to $11.7 \%$ ), Pseudomonadales (from $<1.5$ to $9.4 \%$ ) and Clostridiales (from 10.4 to 12.6\%) orders. The representatives of the Burkholderiales (Alcaligenaceae, Comamonadaceae), Bacteroidales (Porphyromonadaceae), Pseudomonadales (Pseudomonadaceae) orders have been previously described as bacteria able to perform electrochemical interactions with the anode [54-58]. Likewise, the presence of the families Porphyromonadaceae, Comamonadaceae and Pseudomonadaceae were described on the cathode [59] or in cathodic chambers [60].

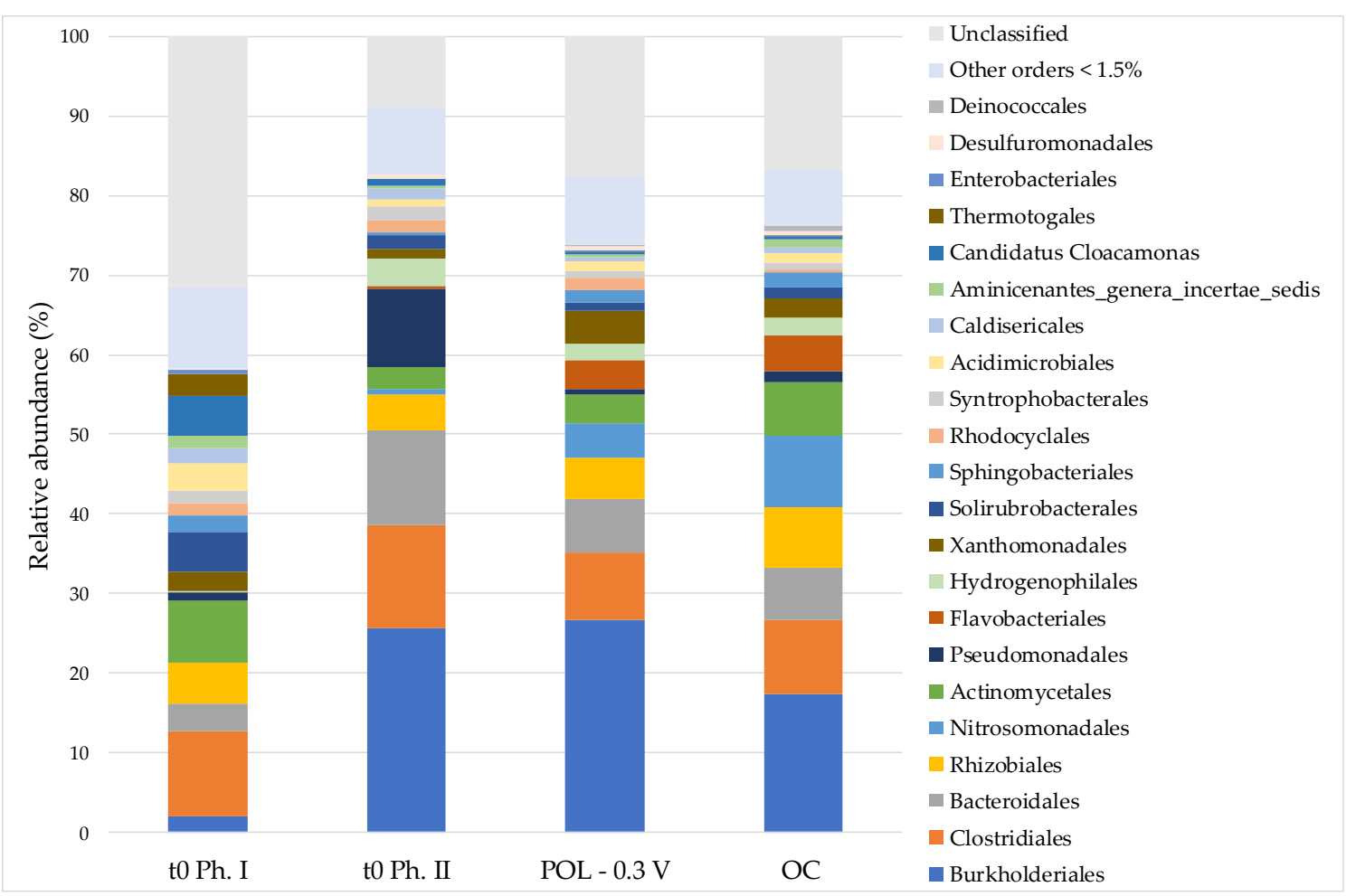

Figure 5. Planktonic bacterial communities structure at order level in the inoculum of MFC (t0 Ph. I), beginning of the second phase ( $\mathrm{t} 0 \mathrm{Ph}$. II), polarized system (POL $-0.3 \mathrm{~V}$ ) and open circuit (OC). "Other orders $<1.5 \%$ " indicated strains with abundance less than $1.5 \%$.

The addition of $\mathrm{Cr}(\mathrm{VI})$ and carbonates as the sole carbon source have influenced the structure of the bacterial community from the beginning of the second phase ( $\mathrm{t} 0 \mathrm{Ph}$. II). Compared to the inoculum, both in POL $-0.3 \mathrm{~V}$ and in OC systems, Pseudomonadales, Bacteroidales and Clostridiales reduced their relative abundances by about $80 \%, 50 \%$ and $30 \%$, respectively. Viceversa, in OC, an increase in the relative abundance of the Nitrosomonadales, from $<1.5 \%$ to $8.8 \%$, was observed. On the other hand, in POL $-0.3 \mathrm{~V}$ there was a slight increase in the orders Burkholderiales due to a net increase in the population of Comamonadaceae, from $2.8 \%$ in $\mathrm{t} 0 \mathrm{Ph}$. II to $10.1 \%$. In the same system also relative abundance of Xanthomonadales increased respect to the inoculum. Both the POL $-0.3 \mathrm{~V}$ and the OC showed relative abundance increase, compared to the inoculum of the bacteria belonging to the Flavobacteriales order, from $0.3 \%$ to $3.6 \%$, and $4.4 \%$, respectively.

The lack of organic electron donors, such as acetate, has influenced the structure of the suspended bacterial community, suggesting a possible advantage for autotrophic microorganisms (Nitrosomonadales and Flavobacteriales) able to use carbonates and ammonium in the mineral medium as carbon source and inorganic electron donor [61]. In the POL $-0.3 \mathrm{~V}$ solution, the presence of the polarized electrode may have favored bacteria belonging to Burkholderiales order (Comamonadaceae 
and Alcaligenaceae families), as already reported in other studies as components of the electroactive communities, enriched from anaerobic digester sludge and chromium tolerant-resistant/autotrophic microrganisms [62-64].

Furthermore, bacteria belonging to these two families have been observed in bioelectrochemical systems, both for the removal of inorganic compounds, such as $\mathrm{H}_{2} \mathrm{~S}$ and $\mathrm{NO}_{3}{ }^{-}$under autotrophic or mixotrophic conditions $[63,65]$, and for $\mathrm{Cr}(\mathrm{VI})$ bioreduction $[21,66]$.

The results of $16 \mathrm{~S}$ rRNA gene sequencing of the biofilms developed on the polarized electrode (POL $-0.3 \mathrm{~V}$ electrode) and on the graphite in the open circuit control (OC graphite) were compared, starting from the order level (Figure 6) and it was deepened on a genus level (Table 2). The Burkholderiales Order, observed in both the solutions of the inoculated systems (17.4\% in OC and $26.8 \%$ in POL $-0.3 \mathrm{~V})$ and in OC graphite $(22.1 \%)$, is present instead with a relative minor abundance on POL $-0.3 \mathrm{~V}$ electrode $(16.5 \%)$. On the polarized bioelectrode bacteria belonging to the orders Flavobacteriales (16.9\% compared to $4.1 \%$ in OC graphite), Rhizobiales (13.7\% compared to $5 \%$ in OC graphite), and Deinococcales (4.9\% compared to $1.7 \%$ in OC graphite) were more abundant; instead the same were almost absent in the planktonic communities (Flavobacteriales 3.6-4.4\%, Rhizobiales $<1.5 \%$, Deinococcales $<1.5 \%$ ).

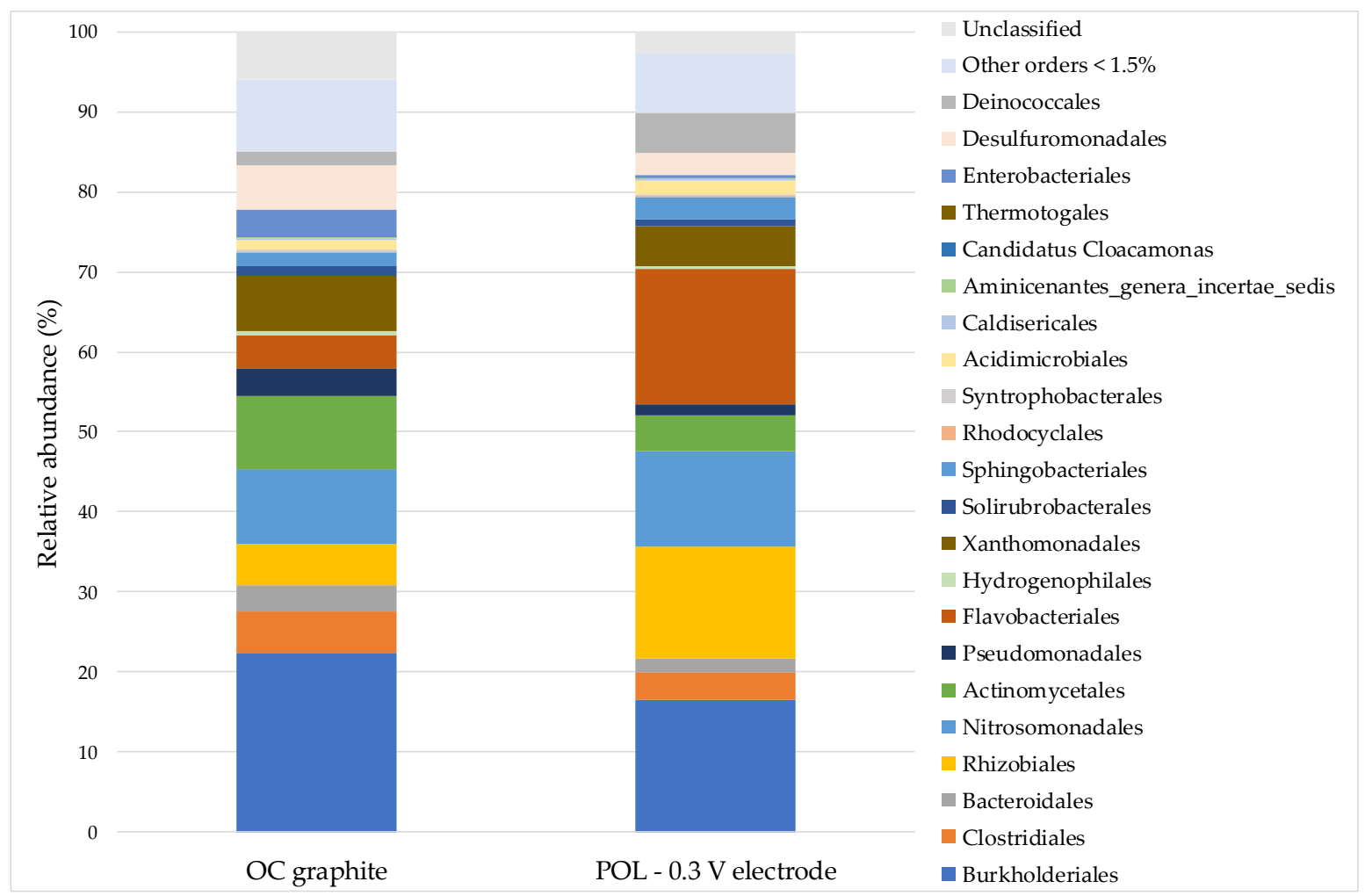

Figure 6. Bacterial community structures at order level of the biofilm developed on graphite of the open circuit system (OC graphite) and on polarized electrode (POL $-0.3 \mathrm{~V}$ electrode). "Other orders $<1.5 \%$ " indicated strains with abundance less than $1.5 \%$.

The only genus detected within the Flavobacteriales order was Moheibacter. Moheibacter was isolated in a cathodic biofilm in a BES for the degradation of oxytetracicline [67] and also in underground rocks, and in anaerobic environment [68]. Schauss and colleagues [69], isolated a novel Moheibacter sp. whit high content of quinone that could be involved in electron transfer to multi-heme c-type cytochromes that have a key role in External Electron Transfer (EET) to electrodes and minerals [12]. The sharp increase in relative abundances of this genus on the polarized bioelectrode, as well as in other electroactive biocathodic communities, as reported in the literature [70,71], may suggest this genus is involved in the transfer of electrons from an electrode. However, to date, there has been no research that has pointed out the Moheibacter is directly implicated in EET. The only genus that was detected 
within the Rhizobiales order was Nitrobacter. Bacteria that belong to the Nitrobacter genus are known for oxidizing nitrite to nitrate, and have been previously observed in autotrophic biocathodes for nitrate removal [72,73]. The whole Deinococcales order was constituted by Truepera genus. This genus has been previously described in electroactive cathodic communities also consisting of microorganisms belonging to the genera Moheibacter and Nitrosomonas [72,74]. Although, an ecological relationship has not yet been defined, the abundance of these genera on the polarized bioelectrode suggests they were at an advantage compared to open circuit system.

Table 2. Relative abundance at order and genus level of the biofilm developed on graphite of the open circuit system (OC graphite) and on polarized electrode (POL $-0.3 \mathrm{~V}$ electrode).

\begin{tabular}{|c|c|c|c|c|}
\hline $\begin{array}{ll}\text { Order } & \text { Genus } \\
\end{array}$ & \multicolumn{2}{|c|}{ OC Graphite (\%) } & \multicolumn{2}{|c|}{ POL -0.3 V Electrode $(\%)$} \\
\hline Burkholderiales & 22.4 & & 16.5 & \\
\hline Advenella & & 14.7 & & 8.2 \\
\hline Cupriavidus & & 2.8 & & 1.6 \\
\hline Polaromonas & & 1.6 & & $<1.5$ \\
\hline Flavobacteriales & 4.2 & & 17.0 & \\
\hline Moheibacter & & 4.1 & & 16.7 \\
\hline Nitrosomonadales & 9.3 & & 11.9 & \\
\hline Nitrosomonas & & 9.1 & & 11.9 \\
\hline Rhizobiales & 5.2 & & 14.0 & \\
\hline Nitrobacter & & $<1.5$ & & 9.9 \\
\hline Actinomycetales & 9.2 & & 4.4 & \\
\hline Rhodococcus & & 5.0 & & 1.5 \\
\hline Xanthomonadales & 6.9 & & 5.0 & \\
\hline Stenotrophomonas & & 3.0 & & 3.1 \\
\hline Dyella & & 3.3 & & $<1.5$ \\
\hline Clostridiales & 5.1 & & 3.5 & \\
\hline Clostridium XI & & 1.8 & & 1.8 \\
\hline Desulfuromonadales & 5.4 & & 2.9 & \\
\hline Geobacter & & 4.2 & & 1.8 \\
\hline Deinococcales & 1.8 & & 4.9 & \\
\hline Truepera & & 1.8 & & 4.9 \\
\hline Bacteroidales & 3.2 & & 1.7 & \\
\hline Petrimonas & & 1.7 & & $<1.5$ \\
\hline Pseudomonadales & 3.3 & & 1.4 & \\
\hline Pseudomonas & & 3.1 & & $<1.5$ \\
\hline Sphingobacteriales & 1.6 & & 2.9 & \\
\hline Enterobacteriales & 3.5 & & $<1.5$ & \\
\hline Escherichia/Shigella & & 3.5 & & $<1.5$ \\
\hline Acidimicrobiales & $<1.5$ & & 1.8 & \\
\hline Other orders $<1.5 \%$ & 8.9 & & 7.5 & \\
\hline Others genera $<1.5 \%$ & & 24.4 & & 21.9 \\
\hline Unclassified order & 6.1 & & 2.7 & \\
\hline Unclassified genus & & 16.1 & & 16.7 \\
\hline
\end{tabular}

\section{Conclusions}

The acclimatization phase in the MFC allowed for the rapid development of the electroactive biofilm, which was able to couple organic substrate oxidation with bioenergy production. Furthermore, the development of an electroactive biofilm shortened the time for $\mathrm{Cr}(\mathrm{VI})$ reduction. The bioelectrode polarized at $-0.3 \mathrm{~V}$ (versus SHE) reduced dissolved $\mathrm{Cr}(\mathrm{VI})$ with larger efficiency (above $90 \%$ ) and/or less time than the controls. Bioelectrochemical reduction overcame both, purely electrochemical reduction, showing only $35 \% \mathrm{Cr}(\mathrm{VI})$ removal under neutral $\mathrm{pH}$, and bioreduction, characterized by high overall efficiency and a significantly slower rate. Furthermore, the bioelectrochemical reduction rate was 20\% faster than the other mechanisms (biological and electrochemical reduction). 
Electroactive biofilm was proven to be essential for the removal of dissolved chromium. Community analyses suggest that Moheibacter, Nitrobacter and Truepera were selectively enriched in the biofilm of the polarized system. Bacteria belonging to the Flavobacteriales, Nitrosomonadales and Rhizobiales orders play a dominant role in electroactive communities enriched in POL $-0.3 \mathrm{~V}$. This work was done to demonstrate, on a laboratory scale, that the bioelectrochemical removal of $\mathrm{Cr}(\mathrm{VI})$ can occur, even in the absence of organic carbon. The results of this study corroborate the results of previous studies, that reported high efficiency in bioelectrochemical $\mathrm{Cr}(\mathrm{VI})$ removal polarized electrodes at $-0.3 \mathrm{~V}$. Although, bioelectrochemical $\mathrm{Cr}(\mathrm{VI})$ reduction requires further research, especially at the pilot scale with real contaminated groundwater, this approach can be considered the basis for a new and sustainable technology for groundwater remediation.

Supplementary Materials: The following are available online at http://www.mdpi.com/2073-4441/12/2/466/s1, Figure S1: Rarefaction curves of bacterial communities based on OTUS, from the following reactors: $\mathrm{t} 0 \mathrm{Ph}$. I, t0 Ph. II, POL - 0.3 V electrode, POL -0.3 V, OC graphite, OC; Table S1: Species richness and diversity estimates.

Author Contributions: Conceptualization, G.B., A.F.M. and E.S.; data curation, A.E.T. and A.F.; formal analysis, G.B., A.E.T., A.F., A.F.M. and E.S.; funding acquisition, S.S.; investigation, G.B., A.F.M. and E.S.; methodology, G.B., A.F.M. and E.S.; supervision, A.F. and S.S.; visualization, G.B., M.D., A.E.T., A.F.M. and E.S.; writing-original draft, G.B., A.E.T., A.F.M. and E.S.; writing-review and editing, G.B., M.D., A.E.T., A.F.M. and E.S. All authors have read and agree to the published version of the manuscript.

Funding: This research was funded by this work was supported by Fondazione Cariplo in the framework of the project BEvERAGE-BioElEctrochemical RemediAtion of Groundwater plumes (2015-0195).

Conflicts of Interest: The authors declare no conflict of interest.

\section{References}

1. Ayyappan, C.S. Microbial leaching of chromium from solidified waste forms-A kinetic study. J. Ecol. Eng. 2015, 16, 36-42. [CrossRef]

2. Tschersich, C.; Barouki, R.; Uhl, M.; Klánová, J.; Horvat, M.; Alimonti, A.; Sarigiannis, D.; Santonen, T.; Lebret, E.; Schoeters, G. Scoping Documents for 2018 Deliverable Report D 4.2-Input for Cd and Cr(VI); Tenical Report for HBM4EU H2020 Programme; 2018; Available online: https://www.hbm4eu.eu/deliverables/ (accessed on 7 February 2020).

3. Mohan, D.; Rajput, S.; Singh, V.K.; Steele, P.H.; Pittman, C.U. Modeling and evaluation of chromium remediation from water using low cost bio-char, a green adsorbent. J. Hazard. Mater. 2011, 188, 319-333. [CrossRef]

4. Song, Z.; Williams, C.J.; Edyvean, R.G.J. Sedimentation of tannery wastewater. Water Res. 2000, 34, $2171-2176$. [CrossRef]

5. Madhavi, V.; Vijay, A.; Reddy, B.; Reddy, K.G.; Madhavi, G.; Nagavenkata, T.; Prasad, K.V. An Overview on Research Trends in Remediation of Chromium. Res. J. Recent Sci. Res. 2013, 2, 71-83.

6. Peng, H.; Guo, J.; Li, B.; Liu, Z.; Tao, C. High-efficient recovery of chromium (VI) with lead sulfate. J. Taiwan Inst. Chem. Eng. 2018, 85, 149-154. [CrossRef]

7. Peng, H.; Leng, Y.; Cheng, Q.; Shang, Q.; Shu, J.; Guo, J. Efficient Removal of Hexavalent Chromium from Wastewater with Electro-Reduction. Processes 2019, 7, 41. [CrossRef]

8. Jobby, R.; Jha, P.; Yadav, A.K.; Desai, N. Biosorption and biotransformation of hexavalent chromium [Cr(VI)]: A comprehensive review. Chemosphere 2018, 207, 255-266. [CrossRef]

9. Daghio, M.; Aulenta, F.; Vaiopoulou, E.; Franzetti, A.; Arends, J.B.A.; Sherry, A.; Suárez-Suárez, A.; Head, I.M.; Bestetti, G.; Rabaey, K. Electrobioremediation of oil spills. Water Res. 2017, 114, 351-370. [CrossRef]

10. Logan, B.E.; Hamelers, B.; Rozendal, R.; Schröder, U.; Keller, J.; Freguia, S.; Aelterman, P.; Verstraete, W.; Rabaey, K. Microbial fuel cells: Methodology and technology. Environ. Sci. Technol. 2006, 40, 5181-5192. [CrossRef]

11. Rabaey, K.; Angenent, L.; Schroder, U.; Keller, J. Bioelectrochemical Systems: From Extracellular Electron Transfer to Biotechnological Application; IWA Publishing: London, UK, 2009; ISBN 9781843392330.

12. Shi, L.; Dong, H.; Reguera, G.; Beyenal, H.; Lu, A.; Liu, J.; Yu, H.-Q.Q.; Fredrickson, J.K. Extracellular Electron Transfer Mechanisms between Microorganisms and Minerals. Nat. Rev. Microbiol. 2016, 14, 651-662. [CrossRef] 
13. An, Z.; Zhang, H.; Wen, Q.; Chen, Z.; Du, M. Desalination combined with hexavalent chromium reduction in a microbial desalination cell. Desalination 2014, 354, 181-188. [CrossRef]

14. Li, Z.; Zhang, X.; Lei, L. Electricity production during the treatment of real electroplating wastewater containing Cr6+ using microbial fuel cell. Process Biochem. 2008, 43, 1352-1358. [CrossRef]

15. Wang, G.; Huang, L.; Zhang, Y. Cathodic reduction of hexavalent chromium [Cr(VI)] coupled with electricity generation in microbial fuel cells. Biotechnol. Lett. 2008, 30, 1959-1966. [CrossRef] [PubMed]

16. Zhang, B.; Feng, C.; Ni, J.; Zhang, J.; Huang, W. Simultaneous reduction of vanadium (V) and chromium (VI) with enhanced energy recovery based on microbial fuel cell technology. J. Power Sources 2012, 204, 34-39. [CrossRef]

17. Huang, L.; Chen, J.; Quan, X.; Yang, F. Enhancement of hexavalent chromium reduction and electricity production from a biocathode microbial fuel cell. Bioprocess Biosyst. Eng. 2010, 33, 937-945. [CrossRef]

18. Tandukar, M.; Huber, S.J.; Onodera, T.; Pavlostathis, S.G. Biological chromium(VI) reduction in the cathode of a microbial fuel cell. Environ. Sci. Technol. 2009, 43, 8159-8165. [CrossRef]

19. Huang, L.; Chai, X.; Quan, X.; Logan, B.E.; Chen, G. Reductive dechlorination and mineralization of pentachlorophenol in biocathode microbial fuel cells. Bioresour. Technol. 2012, 111, 167-174. [CrossRef]

20. Xafenias, N.; Zhang, Y.; Banks, C.J. Enhanced performance of hexavalent chromium reducing cathodes in the presence of Shewanella oneidensis MR-1 and lactate. Environ. Sci. Technol. 2013, 47, 4512-4520. [CrossRef]

21. Thatoi, H.; Das, S.; Mishra, J.; Rath, B.P.; Das, N. Bacterial chromate reductase, a potential enzyme for bioremediation of hexavalent chromium: A review. J. Environ. Manag. 2014, 146, 383-399. [CrossRef]

22. Lovley, D.R.; Phillips, E.J.P. Reduction of Chromate by Desulfovibrio-Vulgaris and Its c3 Cytochrome. Appl. Environ. Microbiol. 1994, 60, 726-728. [CrossRef]

23. Chung, J.; Nerenberg, R.; Rittmann, B.E. Bio-reduction of soluble chromate using a hydrogen-based membrane biofilm reactor. Water Res. 2006, 40, 1634-1642. [CrossRef] [PubMed]

24. Inglett, K.S.; Bae, H.S.; Aldrich, H.C.; Hatfield, K.; Ogram, A.V. Clostridium chromiireducens sp. nov., isolated from Cr(VI)-contaminated soil. Int. J. Syst. Evol. Microbiol. 2011, 61, 2626-2631. [CrossRef] [PubMed]

25. Mclean, J.; Beveridge, T.J. Chromate Reduction by a Pseudomonad Isolated from a Site Contaminated with Chromated Copper Arsenate. Appl. Environ. Microbiol. 2001, 67, 1076-1084. [CrossRef] [PubMed]

26. McLean, J.S.; Beveridge, T.J.; Phipps, D. Isolation and characterization of a chromium-reducing bacterium from a chromated copper arsenate-contaminated site. Environ. Microbiol. 2000, 2, 611-619. [CrossRef] [PubMed]

27. Malaviya, P.; Singh, A. Bioremediation of chromium solutions and chromium containing wastewaters. Crit. Rev. Microbiol. 2016, 42, 607-633. [CrossRef] [PubMed]

28. Wang, H.; Zhang, S.; Wang, J.; Song, Q.; Zhang, W.; He, Q.; Song, J.; Ma, F. Comparison of performance and microbial communities in a bioelectrochemical system for simultaneous denitrification and chromium removal: Effects of pH. Process Biochem. 2018, 73, 154-161. [CrossRef]

29. Xue, H.; Zhou, P.; Huang, L.; Quan, X.; Yuan, J. Cathodic Cr(VI) reduction by electrochemically active bacteria sensed by fluorescent probe. Sens. Actuators B Chem. 2017, 243, 303-310. [CrossRef]

30. Pous, N.; Balaguer, M.D.; Colprim, J.; Puig, S. Opportunities for groundwater microbial electro-remediation. Microb. Biotechnol. 2018, 11, 119-135. [CrossRef]

31. Williams, K.H.; Nevin, K.P.; Franks, A.; Englert, A.; Long, P.E.; Lovley, D.R. Electrode-based approach for monitoring in situ microbial activity during subsurface bioremediation. Environ. Sci. Technol. 2010, 44, 47-54. [CrossRef]

32. Huang, L.; Wang, Q.; Jiang, L.; Zhou, P.; Quan, X.; Logan, B.E. Adaptively Evolving Bacterial Communities for Complete and Selective Reduction of $\mathrm{Cr}(\mathrm{VI}), \mathrm{Cu}(\mathrm{II})$, and Cd(II) in Biocathode Bioelectrochemical Systems. Environ. Sci. Technol. 2015, 49, 9914-9924. [CrossRef]

33. Song, T.S.; Jin, Y.; Bao, J.; Kang, D.; Xie, J. Graphene/biofilm composites for enhancement of hexavalent chromium reduction and electricity production in a biocathode microbial fuel cell. J. Hazard. Mater. 2016, 317, 73-80. [CrossRef] [PubMed]

34. Wu, X.; Zhu, X.; Song, T.; Zhang, L.; Jia, H.; Wei, P. Effect of acclimatization on hexavalent chromium reduction in a biocathode microbial fuel cell. Bioresour. Technol. 2015, 180, 185-191. [CrossRef] [PubMed]

35. Kellner, K.; Posnicek, T.; Ettenauer, J.; Zuser, K.; Brandl, M. A new, low-cost potentiostat for environmental measurements with an easy-to-use PC interface. Procedia Eng. 2015, 120, 956-960. [CrossRef] 
36. Rowe, A.A.; Bonham, A.J.; White, R.J.; Zimmer, M.P.; Yadgar, R.J.; Hobza, T.M.; Honea, J.W.; Ben-Yaacov, I.; Plaxco, K.W. Cheapstat: An open-source, "do-it-yourself" potentiostat for analytical and educational applications. PLoS ONE 2011, 6, e23783. [CrossRef]

37. Eaton, A.D.; Franson, M.A.H. Standard Methods for the Examination of Water and Wastewater, 21st ed.; American Public Health Association, Ed.; American Public Health Association: Washington, DC, USA, 2005; ISBN 9780875530475.

38. Huber, J.A.; Welch, D.B.M.; Morrison, H.G.; Huse, S.M.; Neal, P.R.; Butterfield, D.A.; Sogin, M.L. Microbial population structures in the deep marine biosphere. Science 2007, 318, 97-101. [CrossRef]

39. Wang, Y.; Qian, P.Y. Conservative fragments in bacterial 16S rRNA genes and primer design for 16S ribosomal DNA amplicons in metagenomic studies. PLoS ONE 2009, 4, e7401. [CrossRef]

40. Palma, E.; Daghio, M.; Espinoza Tofalos, A.; Franzetti, A.; Cruz Viggi, C.; Fazi, S.; Petrangeli Papini, M.; Aulenta, F. Anaerobic electrogenic oxidation of toluene in a continuous-flow bioelectrochemical reactor: Process performance, microbial community analysis, and biodegradation pathways. Environ. Sci. Water Res. Technol. 2018, 4, 2136-2145. [CrossRef]

41. Wang, Q.; Garrity, G.M.; Tiedje, J.M.; Cole, J.R. Naïve Bayesian classifier for rapid assignment of rRNA sequences into the new bacterial taxonomy. Appl. Environ. Microbiol. 2007, 73, 5261-5267. [CrossRef]

42. Rismani-Yazdi, H.; Carver, S.M.; Christy, A.D.; Tuovinen, O.H. Cathodic limitations in microbial fuel cells: An overview. J. Power Sources 2008, 180, 683-694. [CrossRef]

43. Lu, L.; Ren, N.; Zhao, X.; Wang, H.; Wu, D.; Xing, D. Hydrogen production, methanogen inhibition and microbial community structures in psychrophilic single-chamber microbial electrolysis cells. Energy Environ. Sci. 2011, 1329-1336. [CrossRef]

44. Wang, Y.-T. Microbial reduction of chromate. In Environmental Microbe-Metal Interactions; American Society of Microbiology: Washington, DC, USA, 2000; pp. 225-235.

45. Viti, C.; Marchi, E.; Decorosi, F.; Giovannetti, L. Molecular mechanisms of Cr(VI) resistance in bacteria and fungi. FEMS Microbiol. Rev. 2014, 38, 633-659. [CrossRef] [PubMed]

46. Huang, L.; Regan, J.M.; Quan, X. Electron transfer mechanisms, new applications, and performance of biocathode microbial fuel cells. Bioresour. Technol. 2011, 102, 316-323. [CrossRef] [PubMed]

47. Focardi, S.; Pepi, M.; Focardi, S.E. Microbial Reduction of Hexavalent Chromium as a Mechanism of Detoxification and Possible Bioremediation Applications. Biodegrad. Life Sci. 2013, 12, 321-348.

48. Vendruscolo, F.; da Rocha Ferreira, G.L.; Antoniosi Filho, N.R. Biosorption of hexavalent chromium by microorganisms. Int. Biodeterior. Biodegrad. 2017, 119, 87-95. [CrossRef]

49. Qu, Y.; Zhang, X.; Xu, J.; Zhang, W.; Guo, Y. Removal of hexavalent chromium from wastewater using magnetotactic bacteria. Sep. Purif. Technol. 2014, 136, 10-17. [CrossRef]

50. Gangadharan, P.; Nambi, I.M. Hexavalent chromium reduction and energy recovery by using dual-chambered microbial fuel cell. Water Sci. Technol. 2015, 71, 353-358. [CrossRef]

51. Li, M.; Zhou, S.; Xu, Y.; Liu, Z.; Ma, F.; Zhi, L.; Zhou, X. Simultaneous Cr(VI) reduction and bioelectricity generation in a dual chamber microbial fuel cell. Chem. Eng. J. 2018, 334, 1621-1629. [CrossRef]

52. Singhvi, P.; Chhabra, M.; Singhvi, P.; Chhabra, M. Simultaneous Chromium Removal and Power Generation Using Algal Biomass in a Dual Chambered Salt Bridge Microbial Fuel Cell. J. Bioremediat. Biodegrad. 2013, $4,190$.

53. Chao, A. Estimating the Population Size for Capture-Recapture Data with Unequal Catchability. Biometrics 1987, 43, 783-791. [CrossRef]

54. Sotres, A.; Díaz-Marcos, J.; Guivernau, M.; Illa, J.; Magrí, A.; Prenafeta-Boldú, F.X.; Bonmatí, A.; Viñas, M. Microbial community dynamics in two-chambered microbial fuel cells: Effect of different ion exchange membranes. J. Chem. Technol. Biotechnol. 2015, 90, 1497-1506. [CrossRef]

55. Barbosa, S.G.; Peixoto, L.; Soares, O.S.G.P.; Pereira, M.F.R.; Heijne, A.T.; Kuntke, P.; Alves, M.M.; Pereira, M.A. Influence of carbon anode properties on performance and microbiome of Microbial Electrolysis Cells operated on urine. Electrochim. Acta 2018, 267, 122-132. [CrossRef]

56. Read, S.T.; Dutta, P.; Bond, P.L.; Keller, J.; Rabaey, K. Initial development and structure of biofilms on microbial fuel cell anodes. BMC Microbiol. 2010, 10, 98. [CrossRef] [PubMed]

57. Joicy, A.; Song, Y.-C.; Lee, C.-Y. Electroactive microorganisms enriched from activated sludge remove nitrogen in bioelectrochemical reactor. J. Environ. Manag. 2019, 233, 249-257. [CrossRef] [PubMed] 
58. Saratale, G.D.; Saratale, R.G.; Shahid, M.K.; Zhen, G.; Kumar, G.; Shin, H.S.; Choi, Y.G.; Kim, S.H. A comprehensive overview on electro-active biofilms, role of exo-electrogens and their microbial niches in microbial fuel cells (MFCs). Chemosphere 2017, 178, 534-547. [CrossRef] [PubMed]

59. Franzetti, A.; Daghio, M.; Parenti, P.; Truppi, T.; Bestetti, G.; Trasatti, S.P.; Cristiani, P. Monod Kinetics Degradation of Low concentration Residual Organics in Membraneless Microbial Fuel Cells. J. Electrochem. Soc. 2017, 164, H3091-H3096. [CrossRef]

60. Yun, H.; Liang, B.; Kong, D.; Wang, A. Improving biocathode community multifunctionality by polarity inversion for simultaneous bioelectroreduction processes in domestic wastewater. Chemosphere 2018, 194, 553-561. [CrossRef] [PubMed]

61. Herrmann, M.; Opitz, S.; Harzer, R.; Totsche, K.; Küsel, K. Attached and Suspended Denitrifier Communities in Pristine Limestone Aquifers Harbor High Fractions of Potential Autotrophs Oxidizing Reduced Iron and Sulfur Compounds. Microb. Ecol. 2017, 74, 264-277. [CrossRef]

62. Fernandez, N.; Sierra-Alvarez, R.; Amils, R.; Field, J.A.; Sanz, J.L. Compared microbiology of granular sludge under autotrophic, mixotrophic and heterotrophic denitrification conditions. Water Sci. Technol. 2009, 59, 1227-1236. [CrossRef]

63. Im, C.H.; Kim, C.; Song, Y.E.; Oh, S.E.; Jeon, B.H.; Kim, J.R. Electrochemically enhanced microbial CO conversion to volatile fatty acids using neutral red as an electron mediator. Chemosphere 2018, 191, 166-173. [CrossRef]

64. Paiva, M.C.; Ávila, M.P.; Reis, M.P.; Costa, P.S.; Nardi, R.M.D.; Nascimento, A.M.A. The microbiota and abundance of the class 1 integron-integrase gene in tropical sewage treatment plant influent and activated sludge. PLoS ONE 2015, 10, e0131532. [CrossRef]

65. Khanongnuch, R.; Di Capua, F.; Lakaniemi, A.-M.; Rene, E.R.; Lens, P.N.L. $\mathrm{H}_{2} \mathrm{~S}$ removal and microbial community composition in an anoxic biotrickling filter under autotrophic and mixotrophic conditions. J. Hazard. Mater. 2018, 367, 397-406. [CrossRef] [PubMed]

66. Morel, M.A.; Iriarte, A.; Jara, E.; Musto, H.; Castro-Sowinski, S. Revealing the biotechnological potential of Delftia sp. JD2 by a genomic approach. AIMS Bioeng. 2016, 3, 156-175. [CrossRef]

67. Chen, J.; Yang, Y.; Liu, Y.; Tang, M.; Wang, R.; Tian, Y.; Jia, C. Bacterial community shift and antibiotics resistant genes analysis in response to biodegradation of oxytetracycline in dual graphene modified bioelectrode microbial fuel cell. Bioresour. Technol. 2019, 276, 236-243. [CrossRef] [PubMed]

68. Mei, J.; Wu, Y.; Qian, F.; Chen, C.; Shen, Y.; Zhao, Y. Methane-Oxidizing Microorganism Properties in Landfills. Polish J. Environ. Stud. 2019, 28, 3809-3818. [CrossRef]

69. Schauss, T.; Busse, H.J.; Golke, J.; Kämpfer, P.; Glaeser, S.P. Moheibacter stercoris sp. Nov., isolated from an input sample of a biogas plant. Int. J. Syst. Evol. Microbiol. 2016, 66, 2585-2591. [CrossRef]

70. Liao, C.; Wu, J.; Zhou, L.; Li, T.; Du, Q.; An, J.; Li, N.; Wang, X. Optimal set of electrode potential enhances the toxicity response of biocathode to formaldehyde. Sci. Total Environ. 2018, 644, 1485-1492. [CrossRef]

71. Sun, J.; Xu, W.; Yang, P.; Li, N.; Yuan, Y.; Zhang, H.; Ning, X.; Zhang, Y.; Chang, K.; Peng, Y.; et al. Enhancing the performance of photo-bioelectrochemical fuel cell using graphene oxide/cobalt/polypyrrole composite modified photo-biocathode in the presence of antibiotic. Int. J. Hydrogen Energy 2018, 44, 1919-1929. [CrossRef]

72. Huang, L.; Wang, Q.; Quan, X.; Liu, Y.; Chen, G. Bioanodes/biocathodes formed at optimal potentials enhance subsequent pentachlorophenol degradation and power generation from microbial fuel cells. Bioelectrochemistry 2013, 94, 13-22. [CrossRef]

73. Xiao, Y.; Zheng, Y.; Wu, S.; Yang, Z.H.; Zhao, F. Bacterial Community Structure of Autotrophic Denitrification Biocathode by 454 Pyrosequencing of the 16S rRNA Gene. Microb. Ecol. 2015, 69, 492-499. [CrossRef]

74. Liao, C.; Wu, J.; Zhou, L.; Li, T.; An, J.; Huang, Z.; Li, N.; Wang, X. Repeated transfer enriches highly active electrotrophic microbial consortia on biocathodes in microbial fuel cells. Biosens. Bioelectron. 2018, 121, 118-124. [CrossRef]

(C) 2020 by the authors. Licensee MDPI, Basel, Switzerland. This article is an open access article distributed under the terms and conditions of the Creative Commons Attribution (CC BY) license (http://creativecommons.org/licenses/by/4.0/). 